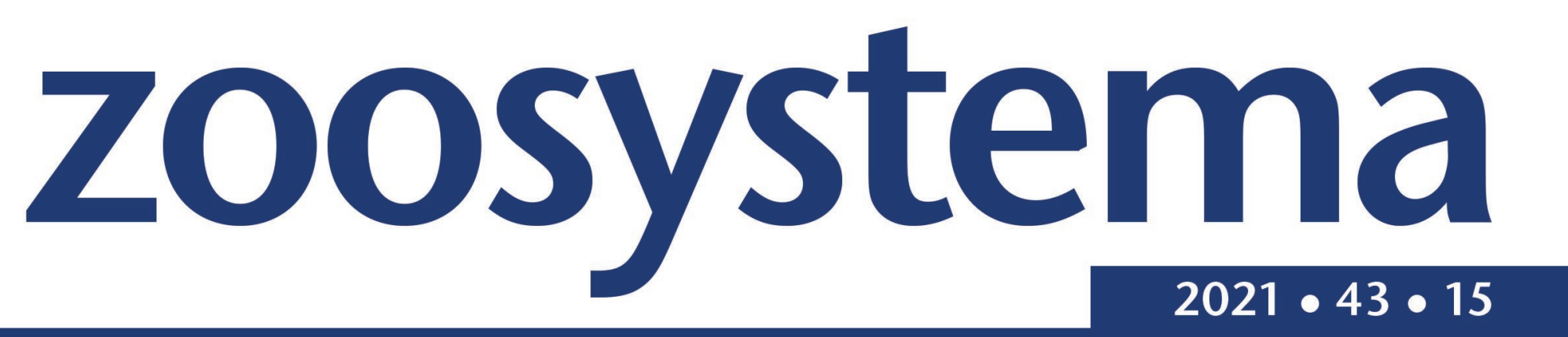

New record of Ectreposebastes niger (Fourmanoir, 1971) (Setarchidae, Scorpaeniformes): a rare bathypelagic fish from La Pérouse Seamount, Western Indian Ocean, and distribution of Ectreposebastes Garman, 1899 in the Indian Ocean

Evgeny V. ROMANOV, Yves CHEREL \& Francis MARSAC

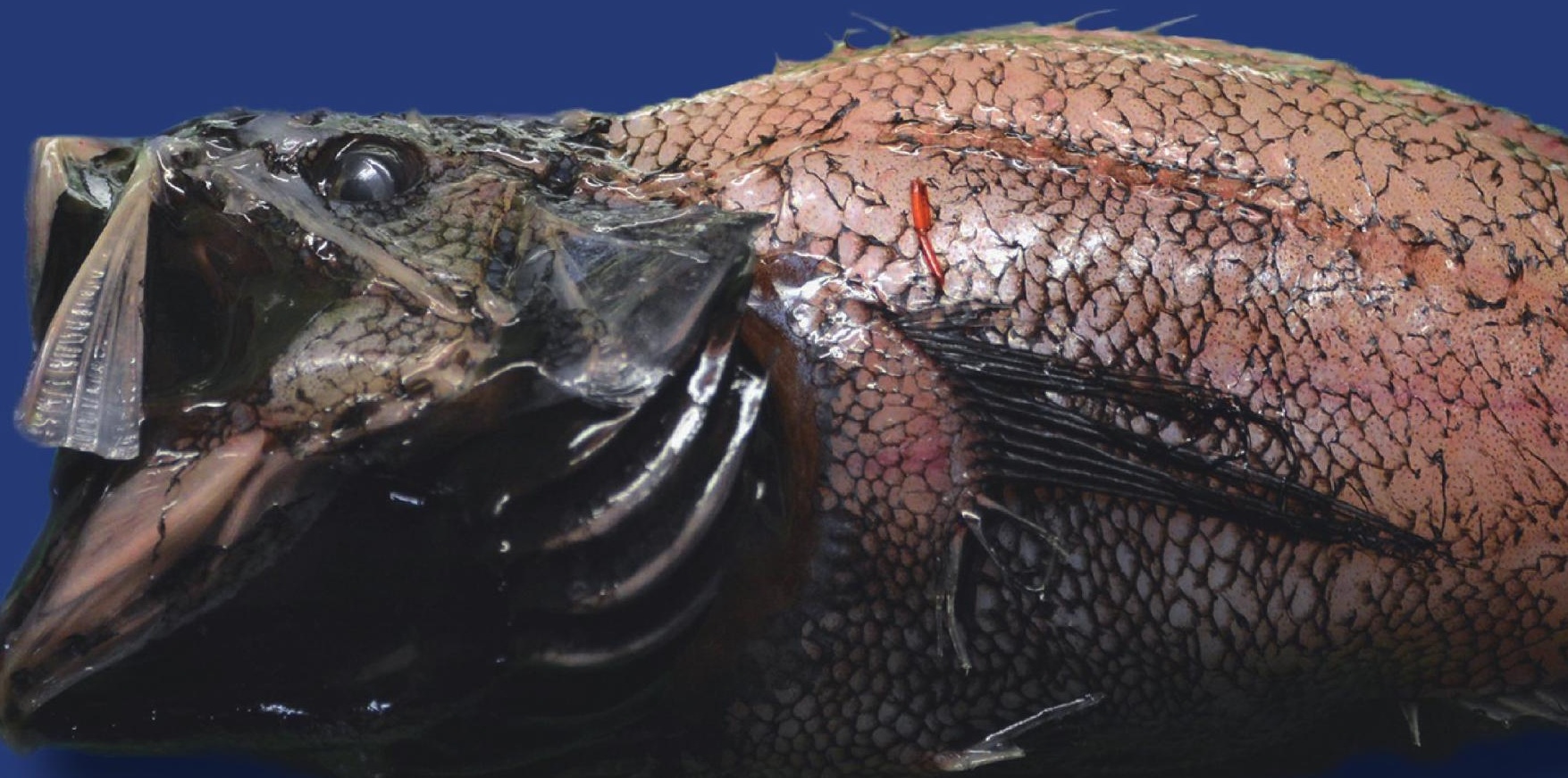


Directeur de LA publication / Publication diRECTOR: Bruno David

Président du Muséum national d'Histoire naturelle

RÉDACTRICE EN CHEF / EDITOR-IN-CHIEF: Laure Desutter-Grandcolas

AsSISTANTE DE RÉDACTION / AsSISTANT EDITOR: Anne Mabille (zoosyst@mnhn.fr)

Mise en PAge / PAge LAYOUt: Anne Mabille

COMITÉ SCIENTIFIQUE / SCIENTIFIC BOARD:

Nesrine Akkari (Naturhistorisches Museum, Vienne, Autriche)

Maria Marta Cigliano (Museo de La Plata, La Plata, Argentine)

Serge Gofas (Universidad de Málaga, Málaga, Espagne)

Sylvain Hugel (CNRS, Université de Strasbourg, France)

Marco Isaia (Università degli Studi di Torino, Turin, Italie)

Rafael Marquez (CSIC, Madrid, Espagne)

Jose Christopher E. Mendoza (Lee Kong Chian Natural History Museum, Singapour)

Annemarie Ohler (MNHN, Paris, France)

Jean-Yves Rasplus (INRA, Montferrier-sur-Lez, France)

Wanda M. Weiner (Polish Academy of Sciences, Cracovie, Pologne)

COUVERTURE / COVER:

Individual of Ectreposebastes niger (Fourmanoir, 1971) caught in the pelagic environment during the LA PÉROUSE cruise. Specimen MNHN-IC-2019-0078.

Photo credit: Francis Marsac.

Zoosystema est indexé dans / Zoosystema is indexed in:

- Science Citation Index Expanded (SciSearch $\left.{ }^{\circledR}\right)$

- ISI Alerting Services ${ }^{\circledR}$

- Current Contents ${ }^{\circledR} /$ Agriculture, Biology, and Environmental Sciences ${ }^{\circledR}$

- Scopus ${ }^{\circledR}$

Zoosystema est distribué en version électronique par / Zoosystema is distributed electronically by:

- BioOne ${ }^{\circledR}$ (http://www.bioone.org)

Les articles ainsi que les nouveautés nomenclaturales publiés dans Zoosystema sont référencés par /

Articles and nomenclatural novelties published in Zoosystema are referenced by:

- ZooBank ${ }^{\circledR}$ (http://zoobank.org)

Zoosystema est une revue en flux continu publiée par les Publications scientifiques du Muséum, Paris / Zoosystema is a fast track journal published by the Museum Science Press, Paris

Les Publications scientifiques du Muséum publient aussi / The Museum Science Press also publish:

Adansonia, Geodiversitas, Anthropozoologica, European Journal of Taxonomy, Naturae, Cryptogamie sous-sections Algologie, Bryologie, Mycologie.

Diffusion - Publications scientifiques Muséum national d'Histoire naturelle

CP 41 - 57 rue Cuvier F-75231 Paris cedex 05 (France)

Tél.: 33 (0)1 40794805 / Fax: 33 (0)1 40793840

diff.pub@mnhn.fr / https://sciencepress.mnhn.fr

(C) Publications scientifiques du Muséum national d'Histoire naturelle, Paris, 2021

ISSN (imprimé / print): 1280-9551/ ISSN (électronique / electronic): 1638-9387 


\title{
New record of Ectreposebastes niger (Fourmanoir, 1971) (Setarchidae, Scorpaeniformes): a rare bathypelagic fish from La Pérouse Seamount, Western Indian Ocean, and distribution of Ectreposebastes Garman, 1899 in the Indian Ocean
}

\author{
Evgeny V. ROMANOV \\ CAP RUN - CITEB (Centre technique de recherche et de valorisation des milieux aquatiques), \\ Magasin n¹0 - Port Ouest, F-97420 Le Port, Île de la Réunion (France) \\ evgeny.romanov@citeb.re (corresponding author) \\ Yves CHEREL \\ Centre d’Études biologiques de Chizé, UMR 7372 du CNRS-La Rochelle Université, \\ F-79360 Villiers-en-bois (France) \\ cherel@cebc.cnrs.fr \\ Francis MARSAC \\ MARBEC, Université Montpellier, CNRS, Ifremer, IRD, \\ avenue Jean-Monnet, CS 30171, F-34203 Sète cedex (France) \\ and IRD, Seychelles Fishing Authority, Fishing Port, P.O Box 449, Victoria, Mahe (Seychelles) \\ francis.marsac@ird.fr
}

Submitted on 28 January 2020 | Accepted on 9 September 2020 | Published on 1 June 2021

urn:Isid:zoobank.org:pub:92D06722-9F7C-4D14-922D-29D15F8C4C0E

Romanov E. V., Cherel Y. \& Marsac F. 2021. - New record of Ectreposebastes niger (Fourmanoir, 1971) (Setarchidae, Scorpaeniformes): a rare bathypelagic fish from La Pérouse Seamount, Western Indian Ocean, and distribution of Ectreposebastes Garman, 1899 in the Indian Ocean. Zoosystema 43 (15): 283-296. https://doi.org/10.5252/zoosystema2021v43a15. http://zoosystema.com/43/15

\section{ABSTRACT}

A new record of a rare deep-water scorpionfish Ectreposebastes niger (Fourmanoir, 1971), is described

KEY WORDS

Deepwater habitat, pseudo-oceanic species, pelagic occurrence,

fish morphology otoliths, genetic analysis, new record.

MOTS CLÉS

Habitat en eau profonde, espèce pseudo-océanique, signalisation pélagique, morphologie des poissons,

analyse génétique,

signalisation nouvelle. from the south-western Indian Ocean. This is the ninth record in the Indian Ocean and the first documented record of this species in the waters of Reunion Island. It is also the first record of this species in the Indian Ocean since 1982. Its congener, Ectreposebastes imus Garman, 1899 is more common: together with non-published records from museums and online databases the number of verified Indian Ocean records exceeds 15 individuals. Both species are pseudo-oceanic, usually associated with continental and peri-insular slopes and seamounts between 200 and $1300 \mathrm{~m}$ depth, occupying a wide range of habitats from demersal to pelagic in the meso- and bathypelagic zones.

\section{RÉSUMÉ}

Nouvelle signalisation d'Ectreposebastes niger (Fourmanoir, 1971) (Setarchidae, Scorpaeniformes) : un rare poisson bathypélagique du mont sous-marin La Pérouse, océan Indien occidental, et répartition d'Ectreposebastes Garman, 1899 dans l'océan Indien.

Le rare poisson pélagique Ectreposebastes niger (Fourmanoir, 1971) est nouvellement signalé du sud-ouest de l'océan Indien, près de l'île de la Réunion. Il s'agit de la neuvième signalisation dans l'océan Indien, la première dans les eaux de l'île de la Réunion, et la première dans l'océan Indien depuis 1982. L'espèce congénérique Ectreposebastes imus Garman, 1899 est plus commune: 15 individus sont mentionnés dans l'océan Indien après analyse de la littérature scientifique, des collections de musées et/ou des bases de données en ligne. Les deux espèces sont pseudo-océaniques étant normalement associées avec les pentes continentales et péri-insulaires et les monts sous-marins entre 200 et $1300 \mathrm{~m}$ de profondeur, où elles occupent une large gamme d'habitats démersaux à semi-pélagiques dans les zones méso- et bathypélagiques. 


\section{INTRODUCTION}

The pelagic scorpionfish Ectreposebastes niger (Fourmanoir, 1971) is a rare deep-water species that inhabits meso- and bathypelagic environments in the Pacific and Indian Oceans (Fourmanoir 1971; Paulin 1982; Mandrytsa 1990; Allen et al. 2006; Motomura \& Struthers 2015). Biology, ecology, habitat and geographic distribution of $E$. niger are still poorly known. This species occasionally occurs in catches of midwater and demersal trawls deployed during commercial and research fishing operations. It was identified and described relatively recently by Fourmanoir (1971) as Pontinus niger. Its validity, however, was immediately challenged: Collette $\&$ Uyeno (1972) synonymized P. niger with Ectreposebastes imus Garman, 1899. While doubts on the identity of $E$. niger and E. imus were expressed by Eschmeyer \& Randall (1975) and by Paulin (1982) (the latter referring to W. N. Eschmeyer pers. comm), the validity of $P$. niger was re-established some 20 years later (Mandrytsa 1990) preserving its place in the genus Ectreposebastes Garman, 1899 (WoRMS Editorial Board 2020). Hence, the genus currently includes two closely-related species: E. imus Garman, 1899 (midwater scorpionfish) and $E$. niger. Scale size and counts as well as proportions of body depth, caudal peduncle, dorsal and pectoral fins, and preopercular spine size are the few morphological characters that allow these species to be distinguished from each other (Eschmeyer \& Randall 1975; Mandrytsa 1990).

Ectreposebastes imus was considered as a single valid species between 1972 and 1990. Therefore, most records of E. imus reported during that period may represent either of the two species.

The midwater scorpionfish $E$. imus is relatively common but not abundant: numerous records of a single or few individuals are known throughout the global oceans from temperate and tropical waters (Eschmeyer \& Collette 1966; Eschmeyer \& Randall 1975; Fourmanoir 1976; Moser et al. 1977; Eschmeyer 1986; Mandrytsa 1990; Poss \& Eschmeyer 2002; Bianchi et al. 2004; Balanov et al. 2009; Escánez \& Brito 2011; Hashim 2012; Govindam et al. 2013; González et al. 2014; Froese \& Pauly 2019; Eduardo et al. 2019). However, because of the similarity between $E$. niger and $E$. imus, their synonymisation in the past, and as the re-establishment of E. niger was published in Russian (Mandrytsa 1990), which may have delayed the recognition of $E$. niger's validity, the distribution and habitat of both species remain obscure at least in the Indo-Pacific.

In the Indian Ocean, both species are known from a few published records. Three individuals of $E$. niger were reported as Ectreposebastes sp. from the Mozambique Channel and Sayade-Malha Bank by Scherbachev et al. (1978), and four other individuals from the Saya-de-Malha Bank and the eastern Indian Ocean by Mandrytsa (1990) (Fig. 1).

Similarly, two specimens of $E$. imus were reported from the Saya-de-Malha Bank and the eastern Indian Ocean by Mandrytsa (1990). Two other individuals from the Arabian Sea and the Bay of Bengal were indicated by Hashim (2012) and two individuals from the Andaman Sea were described by
Kawai et al. (2017). Non-georeferenced sources mentioned the presence of this species off Indonesia (Pauly et al. 1996) and along the south-west coast of India (Govindam et al. 2013).

Here we describe a new record of $E$. niger from the pelagic zone of the tropical southwestern Indian Ocean. Then, we discuss the regional distribution and habitat of both $E$. niger and E. imus based on published data, museum collection inventories accessible from online databases, and other online sources. We also present the first description of otolith shape for $E$. niger and results of genetic sequencing of this species.

\section{MATERIAL AND METHODS}

One individual of Ectreposebastes niger (183 $\mathrm{mm}$ total length (TL); $165 \mathrm{~mm}$ standard length (SL) (Fig. 2) was caught on 18 September 2016 in a midwater trawl by the $R / V$ Antea during the LA PÉROUSE research cruise (https://doi. org/10.17600/16004500). The authors were onboard during the capture, collecting fishing and environmental data, and preserved the specimen. The capture position lay between $19^{\circ} 45.84^{\prime} \mathrm{S}$, $54^{\circ} 05.28^{\prime} \mathrm{E}$ and $19^{\circ} 41.43^{\prime} \mathrm{S}, 54^{\circ} 03.80^{\prime} \mathrm{E}$ (respectively start and end positions of trawling). This midwater trawl was operated in the proximity of La Pérouse Seamount, a steep underwater topographic feature of the southwestern Indian Ocean with an average minimum depth of about $60 \mathrm{~m}$, a crescent-like shape and a length of $12 \mathrm{~km}$ along its largest extension (Marsac et al. 2020). The seamount is situated at 90 nautical miles (nmi) (c. $160 \mathrm{~km}$ ) northwest of the Reunion Island, France (Fig. 1).

The research midwater trawl was an 'International Young Gadoid Pelagic Trawl' (IYGPT) with a horizontal opening of $15.8 \mathrm{~m}$ and a vertical opening of $8 \mathrm{~m}$. A cod-end of $5 \mathrm{~mm}$ stretched mesh was used. The trawl was towed horizontally at 3 knots $\left(c .1 .5 \mathrm{~m} \mathrm{~s}^{-1}\right)$ with a target fishing depth of $500 \mathrm{~m}$, although the range of fished depths was 485-590 m during the set that captured the specimen. The tow was performed between 17:46 (trawl at fishing depth) and 18:55 (trawl at the surface) local time $(\mathrm{GMT}+3)$ with total duration $69 \mathrm{~min}$.

Sea surface temperature (SST) measured during vertical profiling of the water column with CTD probe was $23.6^{\circ} \mathrm{C}$, and the temperature at $500 \mathrm{~m}$ depth was $10.4^{\circ} \mathrm{C}$.

The ocean floor topography (Marsac et al. 2020) shows that the trawl haul was performed over the depths 1400-3000 m at a distance of less than $8 \mathrm{nmi}(c .15 \mathrm{~km})$ west of La Pérouse seamount.

The fish was photographed on board (Fig. 2) with a Nikon D7100 digital camera, resolution $24 \mathrm{Mpx}$, and TL and SL were measured. Otoliths were extracted onboard, cleaned and stored dry separately. After measurement, the specimen was stored frozen at $-18^{\circ} \mathrm{C}$ for $c .90$ days, then was thawed for 12 hours before examination. After measurements, weighing and sampling (muscle samples were taken for DNA analysis) the fish was preserved in $10 \%$ neutral buffered formaldehyde for 48 hours, soaked in freshwater for 4 hours and transferred to $70 \%$ ethanol. The specimen was deposited in the collection of the Museum national d'Histoire naturelle, Paris (catalogue number MNHN-IC-2019-0078). 


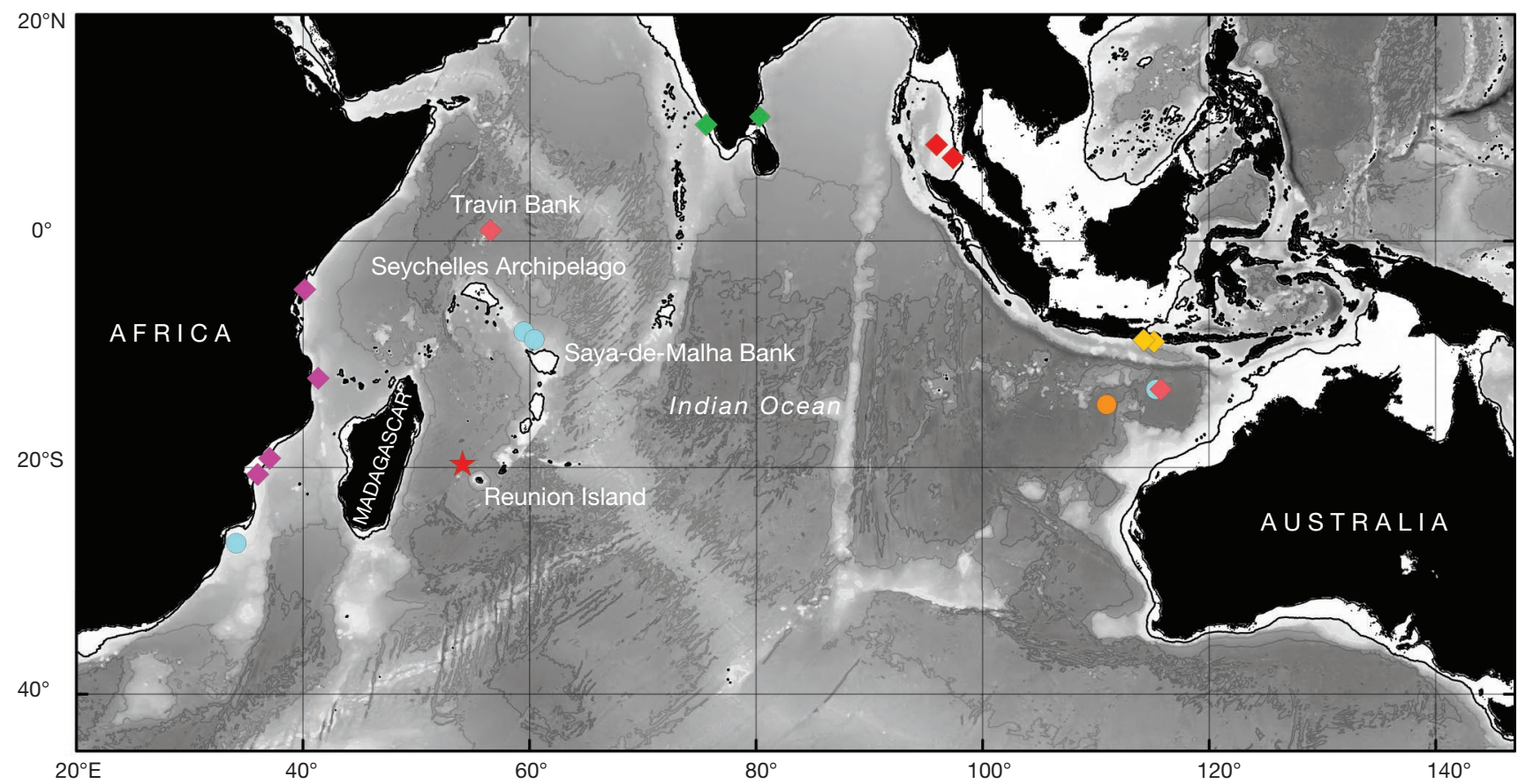

FIG. 1. - Geographic position of Ectreposebastes Garman, 1899 species records from the Indian Ocean. Symbols: E. niger (Fourmanoir, 1971): $\star$, this study; record of MNHN-IC-2019-0078; published records: $\bigcirc$, Mandrytsa (1990); $\bigcirc$, the specimen from the NSMT collection (Dr G. Shinohara, 2019 pers. comm.), also presented in GBIF (wrong position) and ALA 2017 (initial species identification as E. imus Garman, 1899 was modified by ALA team based on empirical criteria without examination of the specimen). E. imus Garman, 1899: Published records: $\diamond$, specimens from YugNIRO cruises (collection ZISP) (Mandrytsa 1990); $\diamond$, Indian records (Hashim 2012); $\diamond$, from a Thailand survey (Kawai et al. 2017). Electronic references: $\diamond$, SAIAB collection records (source: GBIF); $\diamond$, from JETINDOFISH Project expeditions sampling stored both in NHMUK fish collection database and CAS (source; GBIF and NHMUK). Note that the occurrence positions of E. niger and $E$. imus in the Eastern Indian Ocean (Mandrytsa 1990) are artificially jittered to improve visibility and to decrease superposition, however, both individuals were caught in the same trawl. The $200 \mathrm{~m}$ isobaths (black line) and isobaths from 1000 to $5000 \mathrm{~m}$ (in $1000 \mathrm{~m}$ steps, light grey lines) are shown. Coastline and bathymetry data are from GEBCO $(2003,2016)$.

Straight length measurements were taken to the nearest $\mathrm{mm}$ with digital calipers following Eschmeyer \& Collette (1966), Mandrytsa (1990), Kai \& Nakabo (2013) and expressed as percentage of SL. Otoliths (Fig. 3) were examined under a light microscope (Olympus CX41 under $\times 40$ magnification) and photographed with an Olympus E-5 digital camera, resolution $12 \mathrm{Mpx}$. Otolith description followed the terminology of Tuset et al. (2008). Most scales of the specimen were lost, therefore all scale counts correspond to the number of scale pockets.

\section{GENETIC ANALYSIS}

DNA was extracted in the laboratory from muscle tissue taken from the lower cranial area of the fish, close to the otoliths chambers. Tissue was air-dried, minced with a sterile scalpel on a Petri dish and incubated overnight in a Proteinase K and lysis buffer solution. The DNA extraction was completed using the NucleoSpin Tissue Kit (MachereyNagel, Düren, Germany) according to the manufacturer's instructions.

The DNA-barcoding fragment of the mitochondrial cytochrome c oxidase subunit I gene (COI) was amplified using a primer cocktail (Ivanova et al. 2007). All amplifications were performed using illustra ${ }^{\mathrm{TM}}$ PuReTaq $^{\mathrm{TM}}$ Ready-To-Go ${ }^{\mathrm{TM}}$ PCR Beads (GE Healthcare UK, Little Chalfont, UK) in a final volume of $25 \mu \mathrm{L}$ containing $1 \mu \mathrm{L}$ of each primer $(10 \mathrm{pmol} /$ $\mu \mathrm{L}$ ) and 1-2 $\mu \mathrm{L}$ of genomic DNA.
The polymerase chain reaction (PCR) was set to an initial denaturation at $94^{\circ} \mathrm{C}$ for $5 \mathrm{~min}$ followed by 35 cycles of $30 \mathrm{~s}$ at $94^{\circ} \mathrm{C}, 40 \mathrm{~s}$ at $48^{\circ} \mathrm{C}$ and $50 \mathrm{~s}$ at $72^{\circ} \mathrm{C}$ with an additional final elongation phase of $7 \mathrm{~min}$ at $72^{\circ} \mathrm{C}$.

The PCR product was checked via electrophoresis on a $1.5 \%$ agarose gel and product lengths were verified using a 100$1000 \mathrm{bp}$ reference ladder. Ten microliters of PCR product were purified with a $2.5 \mu \mathrm{L}$ mix containing exonuclease I (20 U/ $\mu \mathrm{L})$ and alkaline phosphatase $(1 \mathrm{U} / \mu \mathrm{L})$ using an incubation of $15 \mathrm{~min}$ at $37^{\circ} \mathrm{C}$ and $20 \mathrm{~min}$ at $75^{\circ} \mathrm{C}$.

All purified PCR products were sequenced in both forward and reverse directions by Macrogen Inc. (Amsterdam, the Netherlands) using M13 universal primers.

Forward and reverse sequences were assembled using Geneious (v. R10, Biomatters, Auckland, NZ) and reciprocally verified, and a $555 \mathrm{bp}$ long contig was generated. The sequence was then exported in FASTA format for further analysis. Sequence analysis was performed on Barcoding of Life Data System v. 4 (BOLD) (Ratnasingham \& Hebert 2007) on 1 April 2019 using the Identification Engine, which searches in the entire BOLD reference database for best matches to the query sequence.

Phylogenetic and molecular evolutionary analyses were conducted using MEGA version X software (Kumar et al. 2018). The evolutionary history was inferred using the Neighbor-Joining method (Saitou \& Nei 1987). The evo- 
lutionary distances were computed using the Maximum Composite Likelihood method (Tamura et al. 2004) with 1000 bootstraps using a species that evolved early in the Scorpaeniformes, Trachyscorpia cristulata (Goode \& Bean, 1896), as an outgroup (an individual with BOLD ID ANGBF14113-19). Automatic Barcode Gap Discovery (ABGD) analysis (Puillandre et al. 2012) was applied to check potential species segregation within the genus $E_{c}$ treposebastes, using online web interface available at https:// bioinfo.mnhn.fr/abi/public/abgd/abgdweb.html, consulted 10 August 2020.

\section{INDIAN OCEAN LIMITS}

The Indian Ocean area is considered here following the official description of the International Hydrographic Organisation: from the Asian Continent to Antarctica, with its western and eastern borders positioned at $20^{\circ} \mathrm{E}$ off South Africa and $146^{\circ} 55^{\prime} \mathrm{E}$ off Southern Australia respectively (IHO 1953).

\section{ABBREVIATIONS}

Institutions, collectors (Sabaj 2019)

IRD Institut de Recherche pour le Développement, Marseille;

MNHN Muséum national d'Histoire naturelle, Paris;

NSMT National Museum of Nature and Science, Tokyo.

\section{Databases, programs}

ALA Atlas of Living Australia website at http://www.ala. org.au;

AFORO A web-based environment for shape analysis of fish otoliths. http://aforo.cmima.csic.es/ (Lombarte et al. 2006);

FishBase World Wide Web electronic publication. http:// www.fishbase.org (Froese \& Pauly 2019);

GBIF Global Biodiversity Information Facility. http:// data.gbif.org;

INSD International Nucleotide Sequence Database. https://www.ddbj.nig.ac.jp/insdc-e.html, a joint database of INSDC, International Nucleotide Sequence Database Collaboration. http://www. insdc.org/;

NHMUK Natural History Museum (2014). Dataset: Collection specimens. Resource: Specimens. Natural History Museum Data Portal (data.nhm.ac.uk). https://doi.org/10.5519/0002965, http://data. nhm.ac.uk/;

OBIS The Ocean Biogeographic Information System. https://obis.org/;

SAIAB fish South African Institute for Aquatic Biodiversity fish collection database of the South Africa http://specify-portal.saiab.ac.za/specify-solr/fish/ as on 19.01.2017, currently https://www.gbif.org/ dataset/1aaec653-c71c-4695-9b6e-0e26214dd817, accessed 22 July 2020;

WoRMS World Register of Marine Species http://www. marinespecies.org.

$\begin{array}{ll}\text { Measurements and counts } \\ \text { LL } & \text { lateral line; } \\ \text { OL } & \text { otolith length; } \\ \text { OH } & \text { otolith height; } \\ \text { SL } & \text { standard length; } \\ \text { TL } & \text { total length. }\end{array}$

\section{SYSTEMATIC ACCOUNT}

Family SeTARCHIDAE Matsubara, 1943

Genus Ectreposebastes Garman, 1899

Ectreposebastes niger (Fourmanoir, 1971)

(Fig. 2)

Pontinus niger Fourmanoir, 1971: 42, fig. 6.

TyPe MATERIAL. - Holotype. Pacific Ocean • MNHN-IC-1970-0034, $122 \mathrm{~mm} \mathrm{SL}, 09^{\circ} 56$ 'S, $141^{\circ} 52^{\prime} \mathrm{W}$; 0-1200 m depth; 12.IX.1969; CARIDE 5; R/V Coriolis.

Material eXAmined. - La Réunion • MNHN-IC-2019-0078; no sex data; $165 \mathrm{~mm}$ SL; Southwestern Indian Ocean; 1945.84'S, $54^{\circ} 05.28^{\prime} \mathrm{E}-19^{\circ} 41.43^{\prime} \mathrm{S}, 5^{\circ} 03.80^{\prime} \mathrm{E}$; 18.IX.2016; Romanov, IRD LA PÉROUSE leg; R/V Antea.

Distribution. - Indo-West Pacific meso- and bathy-pelagic, mostly near continental/peri-insular slopes in tropical and temperate waters.

\section{DESCRIPTION}

Individual MNHN-IC-2019-0078 (165 mm SL)

External morphology. Medium-sized, black-coloured scorpaeniform fish with black-yellowish eyes. Pinkish muscles visible through semi-transparent skin in scale pockets; scale pocket edges black. Body relatively high, slightly compressed laterally, flabby, lacking scales (most scales lost, except some pored LL scales) (Fig. 2). Most fin spines, some fin rays broken due to fragile, poorly-ossified nature. First pre-opercular spine weakly developed; others damaged. Lacrimal spines short, intact on the left side but damaged on right. Body proportions shown in Table 1.

Otoliths. Thick and robust. Otolith shape triangular with pointed rostrum (Fig. 3); ventral rim convex; post-dorsal rim almost straight without depression; pre-dorsal rim forming angle close to $90^{\circ}$ with post-dorsal rim. Otolith height almost equal to otolith length (ratio OH/OL 0.75-0.79 for right and left otoliths respectively). Sulcus acusticus: archaesulcoid, ostial, median. Ostium and cauda: undifferentiated, oval. Anterior region: double-peaked; rostrum broad, short, slightly pointed, antirostrum very short, rounded, broad; excisura wide with shallow notch. Posterior region: oblique to round or oblique to irregular.

\section{REMARK}

The morphology of our specimen corresponds well to the original description given by Fourmanoir (1971) and later by Mandrytsa (1990). Body measurements are close to the ranges presented in other studies. However, many proportions are close to or even outside of the lower end of reported ranges (Table 1).

\section{GENETIC ANALYSIS}

A 555 bp region of the mtDNA COI gene was isolated from the specimen and the sequence was deposited in the INSD (accession number: MN181524). The query sequence did not find $100 \%$ match to the mtDNA COI region of any other 


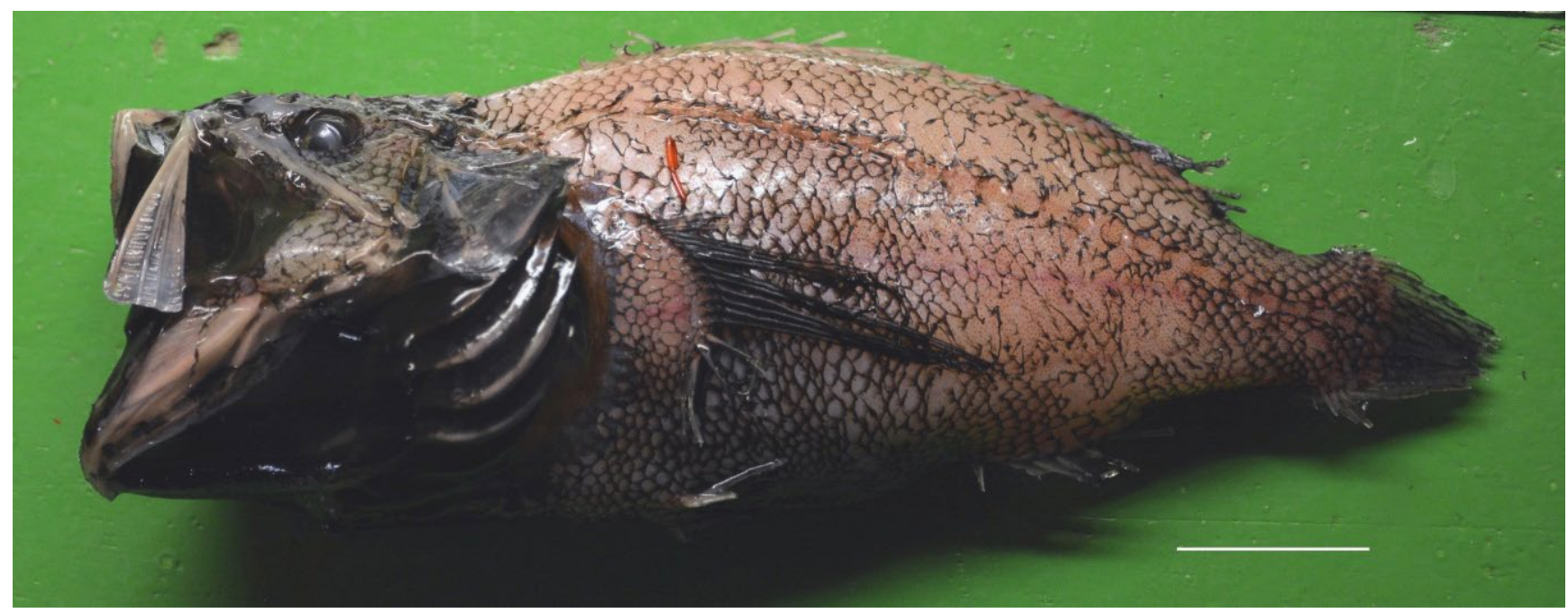

FIG. 2. - Individual of Ectreposebastes niger (Fourmanoir, 1971) caught in the pelagic environment during the LA PÉROUSE cruise. Scale bar: 10 mm. Specimen MNHN-IC-2019-0078. Photo credit: Francis Marsac.

specimens. The nearest matches were non-identified specimens Ectreposebastes sp. (98.13\% to $98.31 \%$ similarity) and Ectreposebastes imus (97.10\% to $98.13 \%$ similarity). Neighbour joining tree analysis (Fig. 6) shows distinct clustering between E. imus, E. niger and Ectreposebastes sp. DNA signatures. The E. imus branch is separated from another branch that contains our E. niger specimen (MN181524) and Ectreposebastes sp. specimens (FOAE60706, FOAF803-07) collected from the Southwestern Pacific: Coral Sea (off Australian coast) and from over Lord Howe Rise.

An ABGD analysis aimed at detecting genetic gaps between species (Puillandre et al. 2012) clustered Ectreposebastes sequences into three lineages, segregating $E$. imus, E. niger (MN181524) and Ectreposebastes sp.

\section{DISCUSSION}

\section{Morphology, GENETICS, IDENTIFICATION}

Morphology and meristic counts of $E$. niger presented here correspond well to other individuals of this species reported in the literature (Table 1). Our specimen is the largest individual of E. niger ever reported globally (Fourmanoir 1971; Paulin 1982; Mandrytsa 1990). Hence, values of body proportions, which are close to or beyond the lower reported range, may represent individual growth-related variability.

Externally, our specimen differs from the congeneric $E$. imus by having larger and fewer scales: lower number of horizontal rows of scales above ( 8 vs 14-16) and below (25 vs 35-48) the LL and lower total number of vertical scale rows (54 vs 83-95) (Mandrytsa 1990). The number of predorsal scales in our individual (11) exceeds the number of predorsal scales observed earlier in E. niger (8-10), but does not overlap with $E$. imus (12-17) (Table 1). It appears that $E$. niger also has shorter pelvic fins and a higher caudal peduncle than E. imus (Table 1). Other interspecific differences mentioned in Mandrytsa (1990) (such as longer dorsal fin base and body height) are highly variable among different individuals (Table 1), often overlapping between species, and cannot be used as identification characters. Length of lacrimal and preopercular spines also cannot be used in many cases as the spines are often broken due to their fragile nature. Apparently, scale size and counts are the sole external indicators that allow intrageneric morphological identification of Ectreposebastes species.

Genetic analysis shows that the level of segregation between Ectreposebastes species is very low. Evolutionary distance between the sequence of our specimen (MN181524) and reference sequences of $E$. imus ranged within 0.0190-0.0248, while distance with Ectreposebastes sp. lies between 0.01700.0190 . However, distinct clustering detected through neighbour joining tree analysis (Fig. 6) indicated segregation of E. imus from E. niger and Ectreposebastes sp. ABGD analysis confirms that $E$. imus and $E$. niger (MN181524) are separate species. At the same time ABGD shows that Ectreposebastes sp. from the Southwestern Pacific and E. niger (MN181524) represents separate linages. Considering that the E. niger holotype originated from the southern Pacific (French Polynesia), the two individuals of Ectreposebastes sp. (FOAE60706, FOAF803-07) collected in the Coral Sea may represent the 'true' E. niger. The genetic divergence of the Indian Ocean lineage identified here as E. niger (MN181524) based on morphological criteria may indicate ongoing allopatric speciation between Pacific and Indian Ocean populations. Further studies are necessary to better understand the level of divergence within $E$. niger across the Indo-Pacific, and therefore genetic sampling, careful examination and preservation are essential for any specimens discovered in the future.

The separation of $E$. niger and $E$. imus remains challenging in view of their overall morphological and genetic similarity. For example, the synonymisation of the two species by 
TABLE 1. - Total length and body proportions (in \% of SL, except TL, SL, otoliths length and height in mm, total weight and otoliths weight in g) of Ectreposebastes niger (Fourmanoir, 1971) from the south-western Indian Ocean and from specimens collected in the Indian Ocean and the Pacific. Comparative measurements for E. imus Garman, 1899 are also given. Measured dimensions are given following terminology of Mandrytsa (1990) and Kai \& Nakabo (2013), except for terms and measurements adopted from Escánez \& Brito (2011) given in italics, and from Frable et al. 2015 given in bold italics. Non-overlapping characters between the two species are underlined. * Including 3 ind. from Scherbachev et al. 1978 (measurements and proportions are taken from Mandrytsa (1990)).

\begin{tabular}{|c|c|c|c|c|c|c|c|}
\hline \multirow[b]{2}{*}{ Measurement } & \multicolumn{4}{|c|}{ Ectreposebastes niger (Fourmanoir, 1971) } & \multicolumn{3}{|c|}{ E. imus Garman, 1899} \\
\hline & $\begin{array}{l}\text { This study, } \\
\text { MNHN- } \\
\text { IC-2019-0078 }\end{array}$ & $\begin{array}{l}\text { holotype } \\
\text { MNHN- } \\
\text { IC-1970-34 }\end{array}$ & $\begin{array}{r}\text { Scherbachev } \\
\text { et al. (1978) }\end{array}$ & $\begin{array}{l}\text { Mandrytsa } \\
\text { (1990) }\end{array}$ & $\begin{array}{c}\text { Mandrytsa } \\
\text { (1990) }\end{array}$ & $\begin{array}{l}\text { Eschmeyer \& } \\
\text { Collette (1966) }\end{array}$ & $\begin{array}{l}\text { Escánez \& } \\
\text { Brito (2011) }\end{array}$ \\
\hline$n$ & 1 & 1 & 3 & $7^{*}$ & 8 & 37 & 2 \\
\hline Total length & 183 & - & - & - & - & - & 84,98 \\
\hline Standard length & 165 & 118 & $90,120,125$ & $\begin{array}{c}112.7 \\
(83.0-141.5)\end{array}$ & $\begin{array}{c}136.9 \\
(55.0-222.0)\end{array}$ & - & 71,83 \\
\hline Snout length & 12.7 & 13.2 & $\begin{array}{c}14.6,14.2 \\
14.1\end{array}$ & $\begin{array}{c}12.5 \\
(11.4-13.6) \\
\end{array}$ & $\begin{array}{c}13.2 \\
(11.5-15.1) \\
\end{array}$ & $\begin{array}{c}14.2 \\
(13.0-17.0)\end{array}$ & $14.1,12.0$ \\
\hline Orbit diameter horizontal & 4.9 & 7.4 & $6.4,7.1,6.9$ & $\begin{array}{c}7.7 \\
(6.8-8.5) \\
\end{array}$ & $\begin{array}{c}7.6 \\
(6.0-9.2) \\
\end{array}$ & - & $7.0,8.4$ \\
\hline Head length & 34.7 & 38.2 & $\begin{array}{c}44.5,40.6 \\
41.4\end{array}$ & $\begin{array}{c}41.0 \\
(38.5-42.9)\end{array}$ & $\begin{array}{c}41.5 \\
(38.6-44.1)\end{array}$ & - & $39.4,45.8$ \\
\hline Interorbital width & 12.5 & 13.5 & $\begin{array}{c}13.2,12.8 \\
13.1\end{array}$ & $\begin{array}{c}12.6 \\
(10.8-13.7) \\
\end{array}$ & $\begin{array}{c}12.6 \\
(11.4-14.2) \\
\end{array}$ & $\begin{array}{c}12.9 \\
(10.0-15.0)\end{array}$ & - \\
\hline Upper jaw length & 23.2 & 23.4 & $\begin{array}{c}25.5,24.6 \\
25.1\end{array}$ & $\begin{array}{c}25.3 \\
(24.6-25.9) \\
\end{array}$ & $\begin{array}{c}24.1 \\
(20.4-26.4) \\
\end{array}$ & - & - \\
\hline Predorsal fin length & 34.0 & 38.5 & $\begin{array}{c}39.4,39.5 \\
39.4\end{array}$ & $\begin{array}{c}36.4 \\
(34.9-38.6) \\
\end{array}$ & $\begin{array}{c}38.3 \\
(30.5-43.3) \\
\end{array}$ & $\begin{array}{c}45.8 \\
(41.0-49.0) \\
\end{array}$ & - \\
\hline Preanal fin length & 71.9 & 77.0 & - & $\begin{array}{c}69.5 \\
(67.4-75.0) \\
\end{array}$ & $\begin{array}{c}70.6 \\
(64.4-76.1) \\
\end{array}$ & - & - \\
\hline Prepectoral fin length & 41.8 & 44.7 & - & $\begin{array}{c}42.6 \\
(40.1-43.7) \\
\end{array}$ & $\begin{array}{c}43.5 \\
(39.2-47.2) \\
\end{array}$ & - & - \\
\hline Prepelvic fin length & 45.5 & - & - & - & - & - & - \\
\hline Body depth (max) & 39.1 & 38.1 & $\begin{array}{c}35.7,32.3 \\
33.4\end{array}$ & $\begin{array}{c}31.8 \\
(28.6-36.1) \\
\end{array}$ & $\begin{array}{c}38.7 \\
(31.9-49.6) \\
\end{array}$ & $\begin{array}{c}42.3 \\
(37.0-52.0) \\
\end{array}$ & $43.7,41.0$ \\
\hline Depth at dorsal fin origin & 37.4 & - & - & - & - & - & - \\
\hline Depth at pelvic fin origin & 37.5 & - & - & - & - & - & - \\
\hline Depth at anal fin origin & 33.6 & - & - & - & - & - & - \\
\hline Caudal peduncle depth & 13.5 & 11.0 & - & $\begin{array}{c}9.5 \\
(8.6-10.0) \\
\end{array}$ & $\begin{array}{c}9.0 \\
(8.0-9.6) \\
\end{array}$ & - & $8.5,8.4$ \\
\hline Length of dorsal fin base & 54.6 & 50.4 & - & $\begin{array}{c}54.8 \\
(50.5-57.4) \\
\end{array}$ & $\begin{array}{c}51.7 \\
(49.2-59.1) \\
\end{array}$ & - & - \\
\hline Spinous dorsal fin base length & 39.6 & - & - & - & - & - & - \\
\hline $\begin{array}{l}\text { Soft rayed dorsal fin base } \\
\text { length }\end{array}$ & 18.1 & - & - & - & - & - & - \\
\hline 1st dorsal fin spine length & 1.2 & 4.1 & - & $\begin{array}{c}6.3 \\
(5.1-7.3) \\
\end{array}$ & $\begin{array}{c}7.0 \\
(6.6-7.2) \\
\end{array}$ & - & - \\
\hline $2^{\text {nd }}$ dorsal fin spine length & 1.7 & - & - & 10.6 & $\begin{array}{c}10.6 \\
(9.9-11.3) \\
\end{array}$ & - & - \\
\hline $3^{\text {rd }}$ dorsal fin spine length & 3.9 & - & - & - & - & - & - \\
\hline $4^{\text {th }}$ dorsal fin spine length & 3.1 & - & - & - & - & - & - \\
\hline $5^{\text {th }}$ dorsal fin spine length & 4.0 & - & - & - & - & - & - \\
\hline Pectoral fin length & 34.8 & 44.7 & $\begin{array}{l}40.0,35.0 \\
35.2\end{array}$ & $\begin{array}{c}38.2 \\
(35.3-40.7)\end{array}$ & $\begin{array}{c}39.7 \\
(32.3-43.6)\end{array}$ & - & $38.0,38.6$ \\
\hline Pectoral fin base depth & 11.9 & - & - & - & - & - & - \\
\hline Pelvic fin ray length & $\underline{9.4}$ & $\underline{18.8}$ & - & $\frac{18.2}{(18.2)}$ & $\begin{array}{r}\frac{23.4}{(22.0-26.4)} \\
\end{array}$ & - & - \\
\hline Pelvic fin spine length & 5.1 & - & - & - & - & - & - \\
\hline
\end{tabular}


Table 1. - Continuation.

\begin{tabular}{|c|c|c|c|c|c|c|c|}
\hline \multirow[b]{2}{*}{ Measurement } & \multicolumn{4}{|c|}{ Ectreposebastes niger (Fourmanoir, 1971) } & \multicolumn{3}{|c|}{ E. imus Garman, 1899} \\
\hline & $\begin{array}{l}\text { This study, } \\
\text { MNHN- } \\
\text { IC-2019-0078 }\end{array}$ & $\begin{array}{l}\text { holotype } \\
\text { MNHN- } \\
\text { IC-1970-34 } \\
\end{array}$ & $\begin{array}{r}\text { Scherbachev } \\
\text { et al. (1978) }\end{array}$ & $\begin{array}{l}\text { Mandrytsa } \\
(1990)\end{array}$ & $\begin{array}{l}\text { Mandrytsa } \\
(1990)\end{array}$ & $\begin{array}{l}\text { Eschmeyer \& } \\
\text { Collette (1966) }\end{array}$ & $\begin{array}{l}\text { Escánez \& } \\
\text { Brito (2011) }\end{array}$ \\
\hline Anal fin base length & 16.0 & 15.9 & - & $\begin{array}{c}16.1 \\
(15.4-17.6)\end{array}$ & $\begin{array}{c}14.4 \\
(13.5-15.6)\end{array}$ & - & - \\
\hline Anal fin spine I length & 2.4 & - & - & $\begin{array}{c}3.7 \\
(2.9-4.5) \\
\end{array}$ & $\begin{array}{c}3.6 \\
(2.7-4.1) \\
\end{array}$ & - & - \\
\hline Anal fin spine II length & 7.9 & - & - & $6.7(5.8-7.7)$ & $8.7(6.6-10.9)$ & - & - \\
\hline Anal fin spine III length & 4.5 & - & - & $9.0(8.4-9.6)$ & $10.8(9.0-12.7)$ & - & - \\
\hline Caudal peduncle dorsal length & 8.1 & - & - & - & - & - & - \\
\hline Caudal peduncle ventral length & 12.6 & $16.1^{*}$ & - & $\begin{array}{c}17.6 \\
(15.5-18.7)^{*}\end{array}$ & $\begin{array}{c}15.8 \\
(13.9-18.4) \\
\end{array}$ & - & - \\
\hline Length of $1^{\text {st }}$ lacrimal spine & 0.8 & 0.8 & - & $1.7(1.3-2.0)$ & $1.4(0.9-2.0)$ & - & - \\
\hline Length of $2^{\text {nd }}$ lacrimal spine & 1.1 & 0.8 & - & $1.6(1.1-2.0)$ & $1.3(1.0-2.9)$ & - & - \\
\hline Length of 1 st preopercular spine & 2.6 & 1.3 & - & $4.1(3.6-4.5)$ & $5.0(3.6-5.8)$ & - & - \\
\hline Length of $2^{\text {nd }}$ preopercular spine & damaged & 1.9 & - & $5.1(3.9-6.1)$ & $6.1(3.9-10.0)$ & - & - \\
\hline Length of $3^{\text {rd }}$ preopercular spine & damaged & 2.5 & - & $6.1(5.9-6.3)$ & $7.3(5.6-9.6)$ & - & - \\
\hline No. dorsal spines & 12 & 12 & 12 & 12 & - & 12 & 12 \\
\hline No. dorsal soft rays & 10 & 10 & 10 & $10(9)$ & - & $9-10$ & 9 \\
\hline No. anal spines & 3 & 3 & 3 & 3 & - & 3 & 3 \\
\hline No. anal soft rays & 6 & 6 & 6 & 6 & - & $5-6$ & 6 \\
\hline No. pectoral rays & 18 & 16 & $18-19$ & $18(16-19)$ & - & $18-20$ & 18,16 \\
\hline No. caudal rays & $\underline{27}$ & - & - & - & - & - & $\underline{20,20}$ \\
\hline No scales on lateral line & 25 & 32 & $27-28$ & $27-28$ & - & - & - \\
\hline $\begin{array}{l}\text { Scales above LL at mid dorsal } \\
\text { fin spiny part }\end{array}$ & $\underline{8}$ & - & $\underline{7}$ & $\underline{8-10}$ & $\underline{14-16}$ & - & $\underline{10,13}$ \\
\hline $\begin{array}{l}\text { Scales below LL at mid dorsal } \\
\text { fin spiny part }\end{array}$ & 25 & - & $19-23$ & $22-32$ & $35-48$ & - & 29,30 \\
\hline Vertical scale raws & $\underline{54}$ & $\underline{55}$ & - & $\underline{55-63}$ & $\underline{83-95}$ & - & - \\
\hline Predorsal scales & $\underline{11}$ & - & $\underline{9-10}$ & $\underline{8-10}$ & $\underline{12-17}$ & - & - \\
\hline Gillrakers on 1 arch & $\begin{array}{c}14 \text { (Upper 6, } \\
\text { Lower 8) }\end{array}$ & - & - & $\begin{array}{c}15-18 \\
(5-7+1+8-10) \\
\end{array}$ & - & - & - \\
\hline Otolith length (L/R) & $3.94 / 3.83$ & - & - & - & - & - & - \\
\hline Otolith height (L/R) & $2.95 / 3.04$ & - & - & - & - & - & - \\
\hline Otolith weight $(\mathrm{L} / \mathrm{R})$ & $0.0097 / 0.0096$ & - & - & - & - & - & - \\
\hline Total weight after defrosting & 142.7 & - & - & - & - & - & - \\
\hline
\end{tabular}

Collette \& Uyeno (1972) was apparently based on misidentification. The individual (NSMT-P 17480) described by Collette \& Uyeno (1972) is obviously distinct from E. niger by its smaller scales ( 12 above LL and 35-38 below LL) representing, therefore, $E$. imus.

The number of pored scales in the LL of Ectreposebastes spp. is an uncertain character. Combined information from available E. niger descriptions given by Fourmanoir (1971), Scherbachev et al. (1978), Mandrytsa (1990) and the present study, suggests 25-32 pored LL scales (Table 1). Most descriptions of $E$. imus are lacking information on the number of LL scales, however, Collette \& Uyeno (1972) reported c. 45 pored scales in the LL of their specimen. Photographs presented in various papers (Eschmeyer \& Randall 1975; Maruyama \& Ono 1975; González et al. 2014) and photos of museum collection specimens stored in SAIAB (catalogue number 82172) and MCZ (catalogue numbers 164078 and 163321) (accessed through GBIF 2020), demonstrate a much lower number of scales in the LL than mentioned by Collette $\&$ Uyeno (1972), close to the range of E. niger.

Otolith shape in teleosts tends to be highly species-specific and is widely used in species identification (Jobling $\&$ Breiby 1986; Smale et al. 1995; Granadeiro \& Silva 2000; Campana 2004, 2005). Here we present the first descrip- 

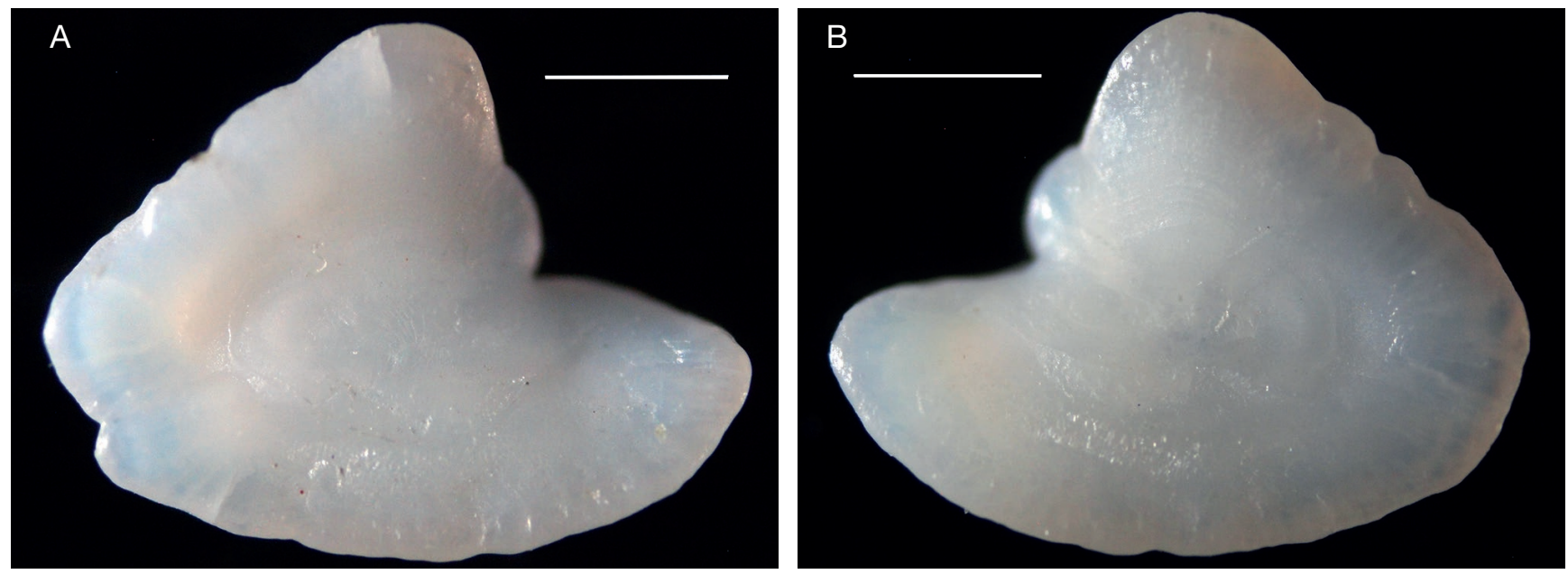

FIG. 3. - Otoliths: left (A), right (B) of Ectreposebastes niger (Fourmanoir, 1971), 165 mm SL, 183 mm TL, reported in this study. MNHN-IC-2019-0078. Scale bars: $1 \mathrm{~mm}$.

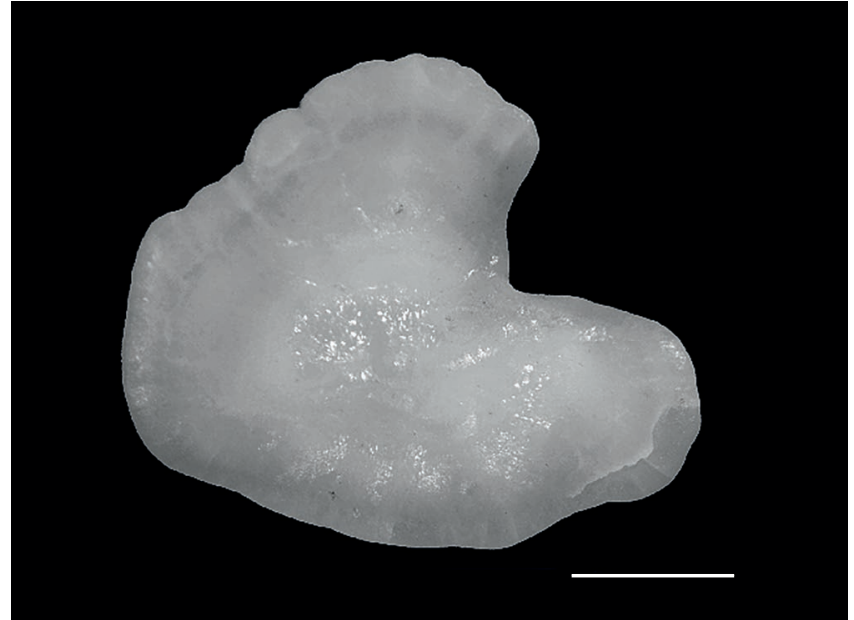

FIG. 4. - Left otolith of Ectreposebastes imus Garman, $1899(160 \mathrm{~mm}$ total length) from Belize, Caribbean Sea, Western Atlantic. Scale bar: $1 \mathrm{~mm}$. Source: AFORO, Fish ID: 9300.

tion of otolith shape of $E$. niger and comparison with its congener E. imus. Otolith OH/OL ratio and overall shape are similar for both species (Figs 3-5). Nevertheless, the otoliths of $E$. niger are clearly distinct from those of $E$. imus of similar sizes. Otoliths of $E$. niger reported in this study had a slightly pointed rostrum and short, rounded antirostrum (Figs 3; 5). In contrast, otoliths of E. imus from specimens $>90 \mathrm{~mm}$ FL presented in Campana (2004) and the AFORO database (Lombarte et al. 2006) demonstrate a rounded rostrum while the antirostrum was either lacking (Campana 2004) or bluntly pointed (Figs 4; 5). The otolith contour of $E$. imus is less 'angular' than that of $E$. niger. Visible differences in otolith shape between $E_{c}$ treposebastes species suggest that this may be an additional robust morphological diagnostic feature. Otolith shape analysis of Pacific E. niger specimens may provide further indicators (besides genetics) on potential divergence from the putative Indian Ocean population.
DisTRIBUTION IN THE INDIAN OCEAN

To date, seven individuals of $E$. niger have been reported in the literature from the Indian Ocean region (Table 2). The first records were described by Scherbachev et al. (1978), who reported three individuals caught by midwater and bottom trawls during Soviet research cruises in the Mozambique Channel and over the Saya-de-Malha Bank (Fig. 1). Scherbachev et al. (1978) identified them as Ectreposebastes sp. (mentioning however differences with $E$. imus) while re-examination by Mandrytsa (1990) finally attributed these individuals to E. niger. Another four individuals were caught, also by the USSR vessels, at the Saya-de-Malha Bank and off Java in 1976-1982, using bottom and midwater trawls respectively (Mandrytsa 1990) (Fig. 1), (Table 2). No new records in the region were reported since.

Direct correspondence with museums allowed us, however, to obtain data on another $E$. niger individual collected from the Indian Ocean. The specimen stored in National Museum of Nature and Science, Tokyo, initially identified as E. imus (NSMT-P 61091) was found in the stomach of a longnose lancetfish Alepisaurus ferox Lowe, 1833 caught in the open Eastern Indian Ocean in 1982 by tuna longline at approximately $170 \mathrm{~m}$ depth (Fig. 1; Table 2). Based on scale counts of the preserved specimen ( 9 horizontal rows above and 34 below LL) and a photograph (G. Shinohara, 2019, pers. comm.) we identified the specimen NSMT-P 61091 as E. niger.

Our record (MNHN-IC-2019-0078) represents the first occurrence of this pelagic scorpionfish in the waters of Reunion Island (Fricke 1999; Letourneur et al. 2004; Fricke et al. 2009) confirming the presence of this species along the Mascarene Ridge: from Saya-de-Malha Bank (past records) to Reunion Island (this study).

Besides the Indian Ocean, E. niger occurrence was documented in the Western and Central Pacific Ocean (Fourmanoir 1971; Paulin 1982; ALA 2017); however, no individual was recorded to date in the Eastern Pacific. 

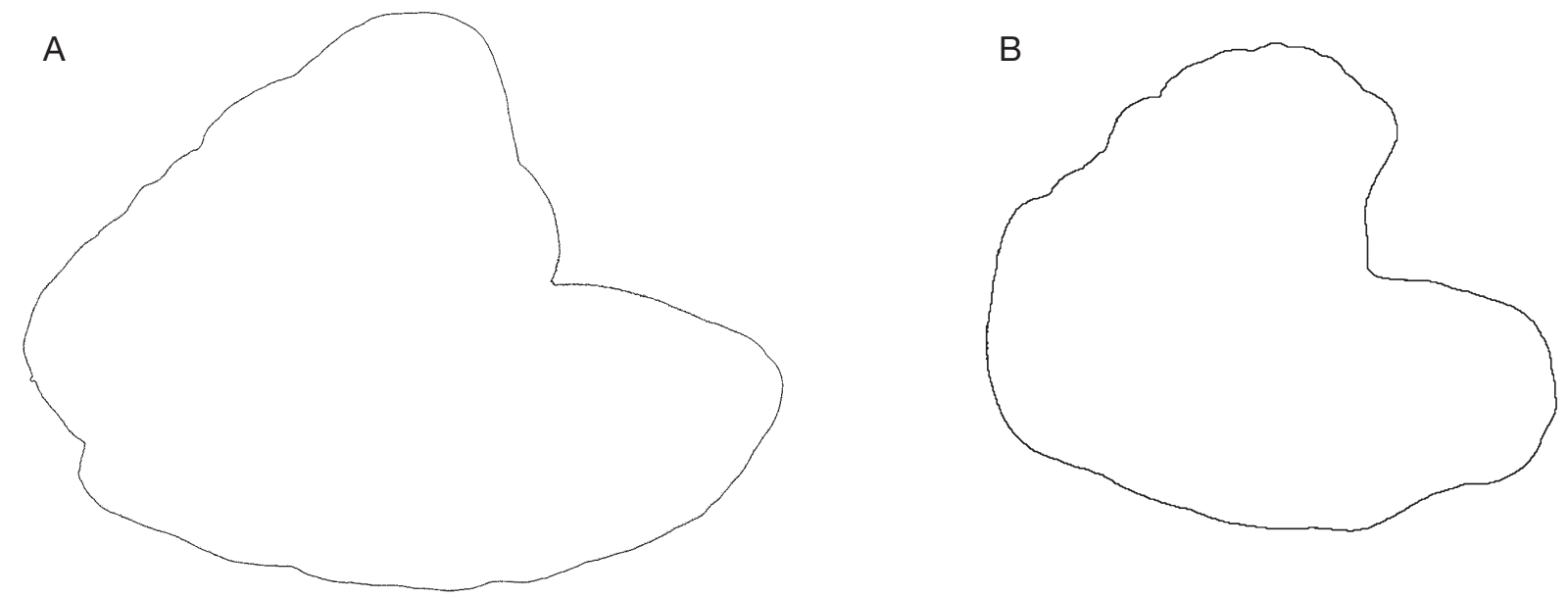

FIG. 5. - Contours of left otoliths of Ectreposebastes Garman, 1899 showing difference in otolith shape between the two species of the genus: A, Ectreposebastes niger (Fourmanoir, 1971) (this study MNHN-IC-2019-0078); B, Ectreposebastes imus Garman, 1899 from Belize, Caribbean Sea, Western Atlantic. Source: AFORO, Fish ID: 9300.

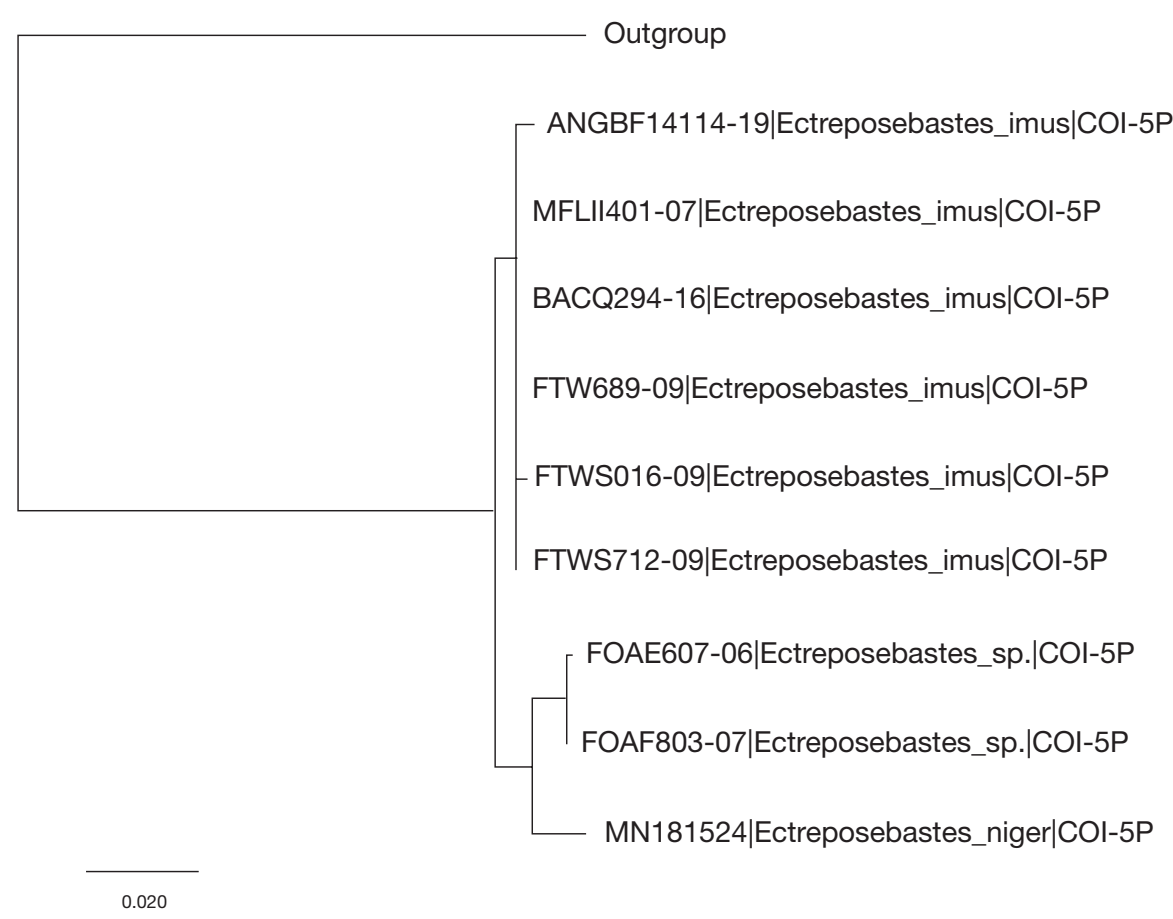

FIG. 6. - Neighbour joining tree of the genus Ectreposebastes Garman, 1899 based on DNA sequences of the mitochondrial COI gene. The tree was constructed based on Ectreposebastes spp. sequences publicly available in Barcoding of Life Data System v. 4 (BOLD) and the sequence from our specimen of Ectreposebastes niger (Fourmanoir, 1971) (MNHN-IC-2019-0078, BOLD accession number: MN181524). The optimal tree with the sum of branch length $=0.22318084$ is shown. The tree is drawn to scale, with branch lengths in the same units as those of the evolutionary distances used to infer the phylogenetic tree. Trachyscorpia cristulata (Goode \& Bean, 1896) (BOLD ID ANGBF14113-19) were used as outgroup.

Occurrences of the congeneric $E$. imus are widely reported throughout the Indian Ocean from the Mozambique Channel, Kenya and in the vicinity of the Travin Bank $\left(00^{\circ} 26^{\prime} \mathrm{N}\right.$, $56^{\circ} 00^{\prime} \mathrm{E}$ ) in the west, through India and the Bay of Bengal to Indonesia in the east (Mandrytsa 1990; Pauly et al. 1996; Hashim 2012; Govindam et al. 2013).
Before this study, the most recent specimen of the genus Ectreposebastes recorded in the south-western Indian Ocean was an individual collected during the pelagic ecosystem survey in Mauritius and the Southern Mascarene region by the R/V Dr. Fridtjof Nansen (Strømme et al. 2010). However, the specimen was not identified to species level and it was 

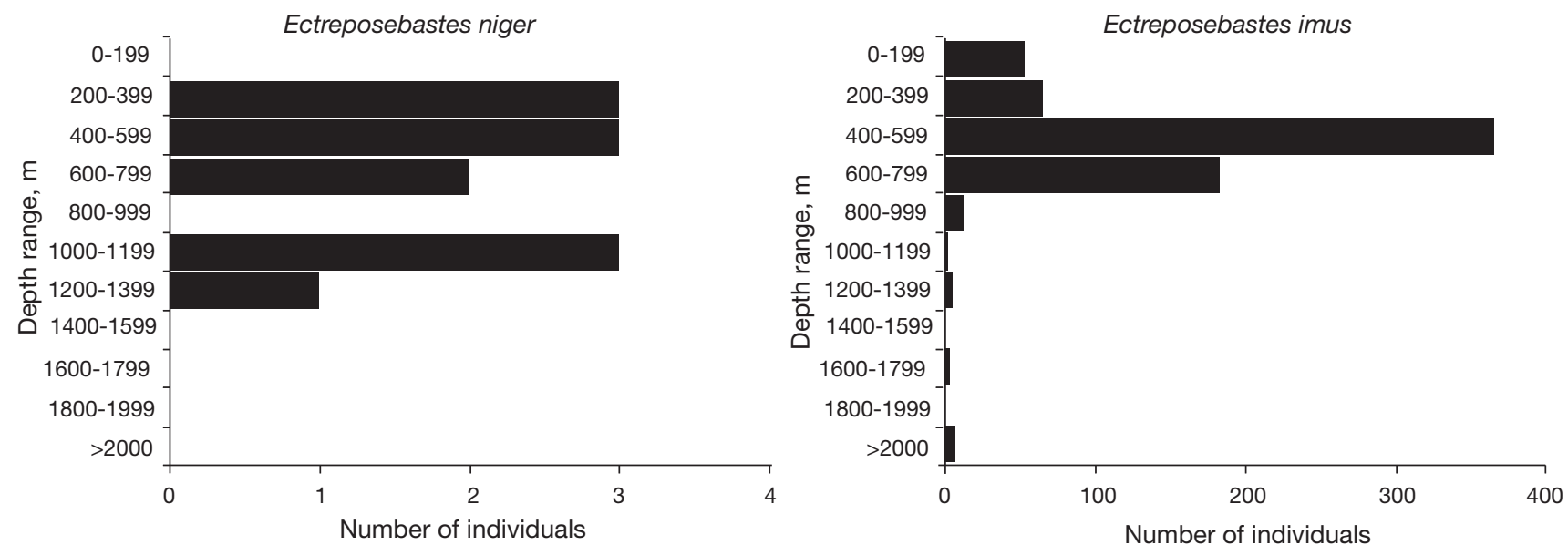

FIG. 7. - Global bathymetric distribution (all records with known capture depth) of Ectreposebastes niger (Fourmanoir, 1971) ( $n=12)$ (left panel) and Ectreposebastes imus Garman, 1899 ( $n=698)$ (right panel). Data sources are listed in Table 2 and also in Eschmeyer \& Collette (1966); Eschmeyer (1969); Collette \& Uyeno (1972); Eschmeyer \& Randall (1975); Maruyama \& Ono (1975); Paulin (1982); Badrudin et al. (2007); Balanov et al. (2009); De Paiva et al. (2011); Escánez \& Brito (2011); González et al. (2014); Chung (2015); ALA, accessed 19 January 2017; GBIF, accessed 19 January 2017; OBIS, accessed 22 July 2020; NHMUK accessed 19 January 2017 . The single record of $E$. niger at the depth of $170 \mathrm{~m}$, which was recovered from a predator's stomach (Alepisaurus ferox) is not considered here.

not possible to locate the specimen or to obtain a copy of the final version of the report.

Non-georeferenced sources also indicate the presence of $E c$ treposebastes species off Indonesia (Pauly et al. 1996; Badrudin et al. 2007) and along the south-west coast of India (Govindam et al. 2013; Venu 2013).

Online databases (OBIS, GBIF) referenced to museum collections (e.g. SAIAB, CSIRO, MCZ) and published records (Eschmeyer 1969; Eschmeyer \& Collette 1966; Maruyama \& Ono 1975; Balanov et al. 2009; De Paiva et al. 2011; Escánez \& Brito 2011; Gonzáles et al. 2014; Tatsuta et al. 2014 , Motomura \& Struthers 2015) confirm the wide occurrence of E. imus (GBIF 2017, 2020; OBIS 2017, 2020) suggesting its circumglobal distribution. Outside the Indian Ocean (Fig. 1) its records spread across the Atlantic, while Pacific occurrences are patchy, mostly in the North and Equatorial Western Pacific, Hawaiian Islands (Central Subtropical Pacific), Galápagos Islands (Eastern Central Pacific) and continental slope of Ecuador and Peru.

It should be mentioned, however, that online databases are always a source of ambiguity in species distributions and taxonomy (Romanov et al. 2013). Online database sources, e.g. Catalog of Fishes (currently Eschmeyer's Catalog of Fishes) (Eschmeyer \& Fricke 2012; Fricke et al. 2020), GBIF, OBIS, SAIAB search portal and ALA are evolving rapidly with changing content, cross-links and URLs. Therefore the use of online databases in their current form without stable URLs and backward content traceability is prone to uncertainty. Their use as a reference and source of data in taxonomic papers is challenging.

A further source of uncertainty in online resources results from several museum specimens that were collected and identified during the period of synonymisation of the two species (CAS, NHMUK): no signs of re-examination are available yet.

\section{HABITAT}

Our results and the available published information suggest that Ectreposebastes species are distributed along continental/ peri-insular shelves, in proximity to seamounts and apparently in deep open-ocean pelagic habitat.

Globally, both species of Ectreposebastes occur in the midwater layer far from the bottom, while catches with demersal trawls (Table 2) and ROV observations on the bottom are also reported (Robertson \& Van Tassell 2019). A summary of distribution occurrences by depth strata (Fig. 7) demonstrates that the habitat of the pelagic scorpionfish, E. niger, ranged from the upper mesopelagic layer (below $200 \mathrm{~m}$ depth) to the bathypelagic depths 1200-1300 m (Mandrytsa 1990). The midwater scorpionfish, E. imus, occurs in the epipelagic zone (shallower than $200 \mathrm{~m}$ ) reaching depths of at least 1000$1150 \mathrm{~m}$ according to published records (Collette \& Uyeno 1972; Grove \& Lavenberg 1997; Badrudin et al. 2007). While most sources (e.g. Eschmeyer 1969) suggest 500-800 m depth as preferred habitat for $E$. imus, our compilation (GBIF 2020; OBIS 2020) demonstrates a wider range, through the entire meso- and bathypelagic zones (Fig. 7).

Most Ectreposebastes occurrences are associated with seamounts (e.g. La Pérouse seamount (this study); Travin Bank, and Saya-de-Malha Bank) or continental slope areas (Fig. 1; Table 2) (Mandrytsa 1990). In Hawaiian waters, E. imus was classified as a potential member of the mesopelagic-boundary community (Reid et al. 1991) and called a 'pseudo-oceanic species' (Hulley \& Lutjeharms 1989), i.e., inhabiting the mesopelagic-boundary zone that 'overlies the depths where mesopelagic waters impinge on the upper slope of a land mass, island or seamount'.

However, the pelagic scorpionfish reported in the present study was caught in the mesopelagic zone together with 'highoceanic fishes' like Benthosema suborbitale (Gilbert, 1913), Ceratoscopelus warmingii (Lütken, 1892), Sigmops elongatus 
TABLE 2. - Details of capture positions of the Indian Ocean Ectreposebastes spp. presented in Fig. 1. Non geo-referenced occurrences are not mapped and not given here. Abbreviations: TRAWB, bottom trawl; TRAWBO, otter trawl; TRAWP pelagic (midwater) trawl; LLP, pelagic longline; ALX, lancetfish Alepisaurus ferox Lowe, 1833; SL, standard length; N/A, non-available. Geographic positions presented in decimal form in the source were converted into dd ${ }^{\circ} \mathrm{mm}$. $\mathrm{m}$ format. * Re-examined and identified as E. niger (Fourmanoir, 1971) by Mandrytsa (1990); ** Apparently collected together. JETINDOFISH Trawl Survey operated in the Indian Ocean (Lohmeyer 1996).

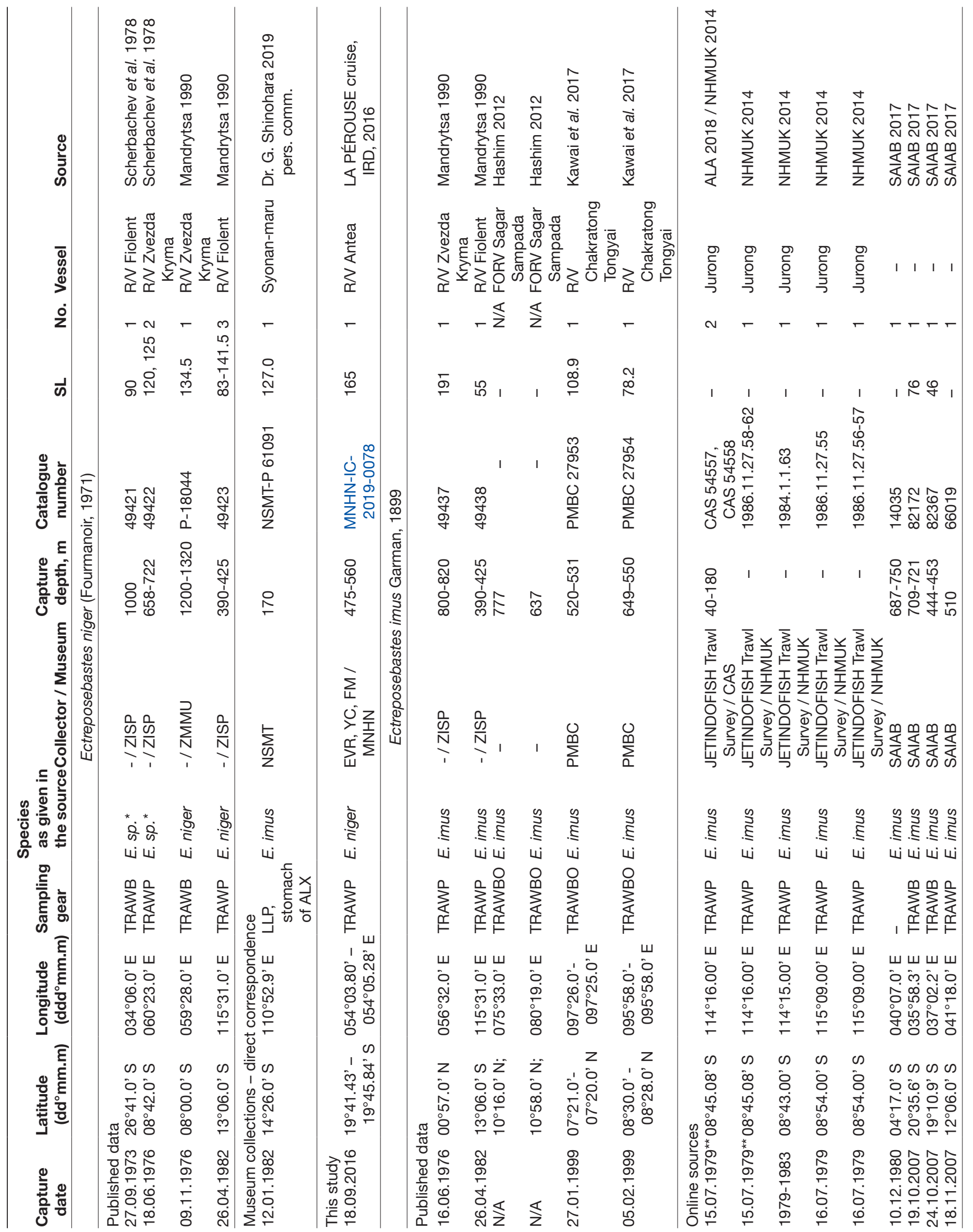


(Günther, 1878), Argyropelecus aculeatus Valenciennes, 1850, Argyropelecus hemigymnus Cocco, 1829, and other highoceanic species from families Evermannellidae Fowler, 1901 and Melamphaidae Gill, 1893 (Cherel et al. 2020). Indeed, several records of adults, juveniles and larvae (Moser $e t$ al. 1977) from pelagic environments show the rather ubiquitous distribution of Ectreposebastes species in the mesopelagic zone of the open ocean.

Alternatively these pelagic records may represent 'lost' individuals transported into oceanic environments by ocean currents. The body shape of Ectreposebastes spp. suggests that both species are not strong swimmers; apparently they are not capable of counteracting a persistent current flow. This renders them vulnerable to predators well adapted to pelagic environment. At least two records of $E$. imus and one of $E$. niger were reported from stomachs of the longnose lancetfish Alepisaurus ferox (Moser et al. 1977; Choy et al. 2013 Suppl.; Shinohara 2019, pers. comm.), which is known as an ambush pelagic predator (Romanov \& Zamorov 2002) inhabiting epi- and mesopelagic layers worldwide.

\section{Acknowledgements}

We are thankful to the captain and the crew of the R/V Antea for their contribution in fishing operations and overall assistance during the research cruise. The laboratory 'biome-id' (Germany) performed DNA barcoding. Dr Gento Shinohara, National Museum of Nature and Science, Japan provided a photograph, scale counts and capture-associated information on the Ectreposebastes specimen from the NSMT collections. Natalya Romanova helped in data compilation on Ectreposebastes bathymetric distribution. The MNHN gives access to the collections in the framework of the RECOLNAT national Research Infrastructure. We appreciate assistance with the English of the manuscript provided by Dr R. Charles Anderson. Two anonymous referees provided valuable suggestions that expand this paper scope and improved its content.

\section{REFERENCES}

Allen G. R., Hoese D. F., Cross N. J. \& Bray D. J. 2006. Sebastidae, Setarchidae, Neosebastidae, Tetratogidae, Synanceiidae, Anthiinae, in BeEsley P. \& Wells A. (eds), Zoological Catalogue of Australia. Volume 35. Fishes. Pt. 2. CSIRO Publishing, Canberra: 866-997.

ALA 2017. — Atlas of Living Australia website. http://biocache.ala. org.au/occurrences/search?\&q=raw_taxon_name $\% 3 \mathrm{~A} \% 22 \mathrm{Ectrep}$ osebastes+imus\%22+OR+raw_taxon_name $\% 3 \mathrm{~A} \% 22$ Ectreposeb astes+imus+Garman $\% 2 \mathrm{C}+1899 \% 22+\mathrm{OR}+$ raw_taxon_name $\% 3$ $\mathrm{A} \% 22$ Ectreposebastes+niger $\% 22+\mathrm{OR}+$ raw taxon name $\% 3 \mathrm{~A} \%$ 22Ectreposebastes+niger+\%28Fourmanoir\%2C+1971\%29\%22. Accessed 19 January 2017.

ALA 2020. - Atlas of Living Australia website at https://bie.ala. org.au/species/urn:lsid:biodiversity.org.au:afd.taxon:e6bc17709be1-4d4a-a876-2c6740f7fd97. Accessed 17 July 2020.

BAdrudin B., Nugroho D. \& Suman A. 2007. - The most abundance and the very rare species in the deep sea fish community in the Western Sumatera, Eastern Indian Ocean. Indonesian Fisheries Research Journal 13: 17-30.
Balanov A. A., Moku M., Kawaguchi K. \& Shinohara G. 2009. - Fishes collected by commercial size midwater trawls from the Pacific Coast off Northern Japan, in FujiTA T. (ed), Deepsea Fauna and Pollutants off Pacific Coast of Northern Japan. National Museum of Nature and Science Monographs 39: 655-681.

BiANCHI G., LundSøR E. \& HAMUKUAYA H. 2004. - On Namibia’s marine fish diversity, in Sumaila U. R., Boyer D., SKogen M. D. \& STEINSHAMN S. I. (eds), Namibia's Fisheries: Ecological, economic and social aspects. Eburon Academic Publishers, Delft: 75-98.

Campana S. E. 2004. - Photographic atlas of fish otoliths of the Northwest Atlantic Ocean. Canadian Special Publication of Fisheries and Aquatic Sciences. NRC Research Press, Ottawa, 284 p.

CAMPANA S. E. 2005. - Otolith science entering the 21 st century. Marine and Freshwater Research 56: 485-495.

Cherel Y., Romanov E. V., Annasawmy P., Thibault D. \& MÉnARD F. 2020. - Micronektonic fish species over three seamounts in the southwestern Indian Ocean. Deep Sea Research Part II: Topical Studies in Oceanography 176: 104777. https:// doi.org/10.1016/j.dsr2.2020.104777

Choy C. A., Portner E., Iwane M. \& Drazen J. C. 2013. Diets of five important predatory mesopelagic fishes of the central North Pacific. Marine Ecology Progress Series 492: 169-184. https://doi.org/10.3354/meps10518

Chung M.-T. 2015. - Functional and life-history traits in deepsea fishes. Ph. D. Thesis. University of Southampton, Southampton, $175 \mathrm{p}$.

Collette B. B. \& Uyeno T. 1972. - Pontinus niger, a synonym of the Scorpionfish, Ectreposebastes imus, with extension of its range to Japan. Japanese Journal of Ichthyology 19: 26-28. https:// doi.org/10.11369/JJI1950.19.26

de Paiva C. C., De Araújo M. E., Caires R. A., Salles R., De Medeiros R. S. \& Da Cruz Lotufo T. M. 2011. - Six new records of deep-sea fish off north-eastern Brazil. Marine Biodiversity Records 4 E9. https://doi.org/10.1017/S1755267210001247.

Eduardo L. N., Mincarone M. M., Villarins B. T., Frédou T., Lira A. S., Bertrand A. \& LuCENA-Frédou F. 2019. — Lengthweight relationships of eleven mesopelagic fishes from oceanic islands of the Southwestern Tropical Atlantic. Journal of Applied Ichthyology 35: 605-607. https://doi.org/10.1111/jai.13840

ESCHMEYER W. N. 1969. - A systematic review of the scorpionfishes of the Atlantic Ocean (Pisces: Scorpaenidae). Occasional Papers of the California Academy of Sciences 79: 1-143.

EsCHMEYER W. N. 1986. - Scorpaenidae, in SMITH M. M. \& HeEmStra P. C. (eds), Smith's Sea Fishes. Springer-Verlag, LondonParis-Tokyo: 463-478

Eschmeyer W. N. \& Collette B. B. 1966. — The scorpionfish subfamily Setarchinae, including the genus Ectreposebastes. Bulletin of Marine Science 16: 349-375.

ESCHMEYER W. N. \& RANDALL J. E. 1975. - The scorpaenid fishes of the Hawaiian Islands, including new species and new records (Pisces: Scorpaenidae). Proceedings of the California Academy of Sciences, 45th ser., 40: 265-334.

ESCHMEYER W. N. \& FricKe R. (EDS) 2012. — Catalog of fishes electronic version (12.02.2012). http://research.calacademy.org/ research/ichthyology/catalog/fishcatmain.asp

ESCÁNEZ A. \& BRITO A. 2011. - First record of the midwater scorpionfish Ectreposebastes imus (Scorpaeniformes: Setarchidae) in the subtropical eastern Atlantic (Canary Islands). Marine Biodiversity Records 4(e78): 1-3. http://doi.org/10.1017/S1755267211000704

FOURMANOIR P. 1971. - Notes ichtyologiques (II). Cahiers ORSTOM, Série Océanographie 8 (3) (1970): 35-46.

FOURMANOIR P. 1976. — Formes post-larvaires et juvéniles de poissons côtiers pris au chalut pélagique dans le sud-ouest Pacifique. Cahiers de l'Indo-Pacifique 19: 47-88.

Frable B. W., Wagman D. W., Frierson T. N., Aguilar A. \& SidLAUSKAS B. L. 2015. - A new species of Sebastes (Scorpaeniformes: Sebastidae) from the northeastern Pacific, with a redescription of the blue rockfish, S. mystinus (Jordan and Gilbert, 
1881). Fishery Bulletin 113: 355-377. http://doi.org/10.7755/ FB.113.4.1

FRICKE R. 1999. - Fishes of the Mascarene Islands (Réunion, Mauritius, Rodriguez). An annotated checklist, with descriptions of new species, Theses Zoologicae Volume 31. Koeltz Scientific Books, Königstein, 759 p.

Fricke R., Mulochau T., Durville P., Chabanet P., Tessier E. \& LETOURNEUR Y. 2009. - Annotated checklist of the fish species (Pisces) of La Réunion, including a Red List of threatened and declining species. Stuttgarter Beiträge Zur Naturkunde A, Neue Serie 2: 1-168.

Fricke R., EsCHMEYER W. N. \& VAN DER LAAN R. (eds) 2020. Eschmeyer's catalog of fishes: genera, species, references. (http:// researcharchive.calacademy.org/research/ichthyology/catalog/ fishcatmain.asp). Electronic version accessed 20 July 2020.

Froese R. \& Pauly D. (eds) 2019. — FishBase. World Wide Web electronic publication. www.fishbase.org, version (12/2019).

GBIF.ORG 2017. — GBIF Occurrence Download http://doi. org/10.15468/dl.nni1tq. Accessed 19 January 2017.

GBIF.ORG 2020. — GBIF Occurrence Download https://doi. org/10.15468/dl.5uezy2. Accessed 22 July 2020.

GEBCO 2003. IOC, IHO and BODC. - Centenary Edition of the GEBCO Digital Atlas, published on CD-ROM on behalf of the Intergovernmental Oceanographic Commission and the International Hydrographic Organization as part of the General Bathymetric Chart of the Oceans, British Oceanographic Data Centre, Liverpool.

GEBCO 2016. — The GEBCO_2014 Grid, version 20150318. www.gebco.net

GonzÁlez J. A., Martins A., Santana J. I., Triay-Portella R., Monteiro C., Garcia-Martin V., Jiménez S., GonZÁlezLorenzo G., Pajuelo J. G., Lorenzo J. M. \& Biscoito M. 2014. - New and rare records of teleost fishes from the Cape Verde Islands (eastern-central Atlantic Ocean). Cybium 38: 289-300.

Govindam S. V. S., Sreedhar U. \& Kumari B. M. 2013. Abundance, bathymetric distribution and diversity of deep sea demersal finfish resources along the south-west coast of India. Indian Journal of Fisheries 60: 1-6.

Granadeiro J. P. \& Silva M. A. 2000. - The use of otoliths and vertebrae in the identification and size-estimation of fish in predator-prey studies. Cybium, 24: 383-393.

Grove J. S. \& LAVEnBerG R. J. 1997. — The fishes of Galápagos Islands. Stanford University Press, Stanford, 912 p.

Hashim M. 2012. — Distribution, diversity and biology of deepsea fishes in the Indian EEZ. Ph.D. Thesis. Cochin University of Science and Technology, Kochi, India, $184 \mathrm{p}$.

Hulley P. A. \& LuTJeHARMS J. R. E. 1989. - Lanternfishes of the southern Benguela region. Part 3. The pseudoceanic-oceanic interface. Annals of the South African Museum 98: 409-435.

IHO (INTERNATIONAL HYDROGRAPHIC ORGANIZATION) 1953. Limits of oceans and seas. 3rd edition. International Hydrographic Organization, Monaco, Special Publication (S-23) 23: 38 p.

IVANova N. V., ZemlaK T. S., Hanner R. H. \& HeberT P. D. N. 2007. - Universal primer cocktails for fish DNA barcoding. Molecular Ecology Resources 7: 544-548.

Jobling M. \& BREIBY A. 1986. - The use and abuse of fish otoliths in studies of feeding habits of marine piscivores. Sarsia 71: 265-274.

KaI Y. \& NaKabo T. 2013. - Taxonomic review of the Sebastes pachycephalus complex (Scorpaeniformes: Scorpaenidae). Zootaxa 3637: 541-560.

KaWai T., Tashiro F., Imamura H. \& Aungtonya C. 2017. Deep-sea fishes collected from the Andaman Sea by R/V Chakratong Tongyai during 1996-2000. Part 1: Order Scorpaeniformes. Phuket Marine Biological Center Research Bulletin 74: 23-32.

Kumar S., Stecher G., Li M., Knyaz C. \& Tamura K. 2018. MEGA X: Molecular Evolutionary Genetics Analysis across computing platforms. Molecular Biology and Evolution 35:1547-1549.
Letourneur Y., Chabanet P., Durville P., Taquet M., Teissier E., Parmentier M., Quéro J.-C. \& Pothin K. 2004. — An updated checklist of the marine fish fauna of Reunion Island, south-western Indian Ocean. Cybium 28:199-216.

LOHMEYER U. 1996. - Narrative and major results of the Indonesian-German Module (II) of the JETINDOFISH Project, August 1979 to July 1981, in Pauly D. \& Martosubroto P. (eds), Baseline Studies of Biodiversity: The Fish Resources of Western Indonesia. ICLARM Studies and Reviews 23: 77-90.

lombarte A., Chic Ò., Parisi-Baradad V., Olivella R., Piera J. \& GARCÍA-LADONA E. 2006. - A web-based environment for shape analysis of fish otoliths. The AFORO database. Scientia Marina 70: 147-152.

MANDRYTSA S. A. 1990. - On the validity of Ectreposebastes niger and distribution of species of the genus Ectreposebastes (Pisces, Scorpaenidae), in Trudy Zoologicheskogo Instituta, Akademii Nauk SSSR 213: 29-34. [In Russian, English summary.]

Marsac F., Annasawmy P., Noyon M., DemarcQ H., Soria M., Rabearisoa N., Bach P., Cherel Y., Grelet J. \& Romanov E. 2020. - Seamount effect on circulation and distribution of ocean taxa in the vicinity of La Pérouse, a shallow seamount in the southwestern Indian Ocean. Deep Sea Research Part II: Topical Studies in Oceanography 176: 104715. https://doi. org/10.1016/j.dsr2.2020.104806

MarUYAMA K. \& ONO K. 1975. - On the specimens of Scorpaenid fish Ectreposebastes imus from off Kamaishi, Japan. Japanese Journal of Ichthyology 21: 233-234.

Moser H. G., Ahlstrom E. H. \& SAndKnop E. M. 1977. — Guide to the Identification of Scorpionfish Larvae (Family Scorpaenidae) in the Eastern Pacific With Comparative Notes on Species of Sebastes and Helicolenus From Other Oceans. NOAA Technical Report NMFS 402. NOAA NMFS. 71 p.

Motomura H. \& STruthers C. D. 2015. - The Fishes of New Zealand. Volume Three. Systematic Accounts. 154 Family Setarchidae (1083-1085), in RoberTs C. D., STEWART A. L. \& Struthers C. D. (eds), The Fishes of New Zealand. Volume 3. Te Papa Press, Wellington: 577-1152.

Natural History Museum 2014. - Dataset: Collection specimens. Resource: Specimens. Natural History Museum Data Portal (data.nhm.ac.uk). https://doi.org/10.5519/0002965, Retrieved: 13:11 26 December 2018 (GMT)

OBIS 2020. - Ocean Biogeographic Information System. Intergovernmental Oceanographic Commission of UNESCO. https:// obis.org/

PAUlin C. D. 1982. - Scorpionfishes of New Zealand (Pisces: Scorpaenidae). New Zealand Journal of Zoology 9: 437-450. http://doi.org/10.1080/03014223.1982.10423875

Pauly D., Cabanban A. \& Torres F. S. B. 1996. - Fishery Biology of 40 trawl-caught teleosts of Western Indonesia, in PAULY D. \& Martosubroto P. (EDS), Baseline Studies of Biodiversity: The Fish Resources of Western Indonesia. ICLARM Studies and Reviews 23: 135-216.

Poss S. G. \& EsCHMEYER W. N. 2002. — Scorpaenidae, in CARPENTER K. E. (ed) The living marine resources of the Western Central Atlantic. Volume 2: Bony fishes part 1 (Acipenseridae to Grammatidae). FAO Species Identification Guide for Fishery Purposes and American Society of Ichthyologists and Herpetologists Special Publication No. 5. Rome, FAO: 1232-1265.

Puillandre N., Lambert A., Brouillet S. \& Achaz G. 2012. ABGD, Automatic Barcode Gap Discovery for primary species delimitation. Molecular Ecology 21:1864-1877. https://doi. org/10.1111/j.1365-294X.2011.05239.x

RATNASINGHAM S. \& Hebert P. D. N. 2007. - BOLD: The Barcode of Life Data System (www.barcodinglife.org). Molecular Ecology Notes 7: 355-364. https://doi.org/10.1111/j.14718286.2006.01678.x

Reid S. B., Hirota J., Young R. E. \& Hallacher L. E. 1991. Mesopelagic-boundary community in Hawaii: Micronekton at 
the interface between neritic and oceanic ecosystems. Marine Biology 109: 427-440. https://doi.org/10.1007/BF01313508

RoberTSON D. R. \& VAN TASSELl J. 2019. - Shorefishes of the Greater Caribbean: online information system. Version 2.0 Smithsonian Tropical Research Institute, Balboa, Panamá. https:// biogeodb.stri.si.edu/caribbean/en/pages. Accessed 5 August 2020.

Romanov E. V. \& Zamorov V. V. 2002. — First record of a yellowfin tuna (Thunnus albacares) from the stomach of a longnose lancetfish (Alepisaurus ferox). Fishery Bulletin 100: 386-389.

Romanov E. V., Bach P., Rebik S. T., Le Turc A. \& Séret B. 2013. - First pelagic record of the velvet dogfish Zameus squamulosus (Günther, 1877) (Squaliformes) from the southwestern Indian Ocean and some notes on its regional distribution. Zoosystema 35: 11-23. https://doi.org/10.5252/z2013n1a2

SABAJ M. H. 2019. - Standard symbolic codes for institutional resource collections in herpetology and ichthyology: An Online Reference. Version 7.1 (21 March 2019). American Society of Ichthyologists and Herpetologists, Washington, DC. Electronically accessible at: https://asih.org/standard-symbolic-codes/ about-symbolic-codes

Saitou N. \& NeI M. 1987. — The neighbor-joining method: A new method for reconstructing phylogenetic trees. Molecular Biology and Evolution 4: 406-425.

SCherbacheV Y. N., LeVITSKY V. N. \& PORTSEV P. I. 1978. - On records of the rare species of deep-sea fishes from off Southern Africa. Trudy Instituta Okeanologii 11: 185-194. [In Russian].

Smale M. J., Watson G. \& HeCHT T. 1995. — Otolith atlas of southern African marine fishes. Ichthyological Monographs of the J.L.B. Smith Institute of Ichthyology. Issue 1. Grahamstown, xiv, 253 p., 149 plates.

Strømme T., Alvheim O. \& Groeneveld J. 2010. - Cruise report "Dr. Fridtjof Nansen" Mauritius and Southern Mascarene: Pelagic Ecosystem Survey, SWIOFP/ FAO 2010, Cruise 16 6-21 December 2010. Preliminary report. Institute of Marine Research, Bergen. Tamura K., Nei M. \& Kumar S. 2004. — Prospects for inferring very large phylogenies by using the neighbor-joining method. Proceedings of the National Academy of Sciences 101: 11030-11035.

Tatsuta N., Imamura H., NaKaya K., KaWai T., AbE T., SaKaOKa K., TAKAGI S. \& YABE M. 2014. - Taxonomy of mesopelagic fishes collected around the Ogasawara Islands by the T/S OshoroMaru. Memoirs of the Graduate School of Fisheries Sciences Hokkaido University 56: 1-65.

Tuset V. M., Lombarte A. \& Assis C. A. 2008. - Otolith atlas for the western Mediterranean, north and central eastern Atlantic. Scientia Marina 72S1: 7-198.

VENU S. 2013. - Deep-sea fish distribution along the south-west region of Indian EEZ, in VenKataraman K., Sivaperuman C. \& Raghunathan C. (eds), Ecology and Conservation of Tropical Marine Faunal Communities. New York, Dordrecht, London: Springer-Verlag Berlin Heidelberg: 261-281. https:// doi.org/10.1007/978-3-642-38200-0

WORMS EDITORIAL BOARD 2018. - World Register of Marine Species. Available from http://www.marinespecies.org at VLIZ. Accessed 1 December 2018. https://doi.org/10.14284/170

Submitted on 28 January 2020 accepted on 9 September 2020; published on 1 June 2021. 